\title{
Job Seeking and Daily Workforce Experiences of Autistic Librarians
}

Amelia Anderson, Old Dominion University, USA

\begin{abstract}
Anecdotal accounts suggest that librarianship is a rewarding career for some autistic adults, though no empirical evidence exists to support such claims. Additionally, barriers may exist for autistic librarians, both in job seeking and in on-the-job experiences. As autistic adults are unand underemployed more than their neurotypical peers, it is important to understand the role that libraries can play in supporting their employment. In this qualitative study, ten librarians with graduate degrees, who self-identify as autistic, describe their experiences in job seeking and daily working experiences in the library field through interviews in multiple formats. Results indicate issues around disclosure and accessibility, and that librarians thrive when their skills are prioritized and when they feel like they are helping or doing meaningful work. Additionally, these librarians find their way into the profession through exposure to libraries and take comfort in working with like-minded people. Finally, autistic librarians in this study describe the hope that hiring managers and library supervisors have at least some knowledge and understanding of autism, along with the willingness to learn more.
\end{abstract}

Keywords: accessibility; autism; employment

Publication Type: research article

\section{Introduction}

ibrarianship claims to be an inclusive field, with a core value of the profession being a commitment to diversity (American Library Association, 2019). However, it is unclear how this commitment to diversity translates to librarians who are neurodivergent and, more specifically, autistic. ${ }^{1}$ In this research article, autism, or Autism Spectrum Disorder (ASD), is defined as a developmental disability that affects how people think, communicate, and interact with the world (ASAN, 2021).

Research into the experience of autistic adults is only meaningful when the results have value for members of the population itself. This study utilized inclusive practices to ensure voices of participants were accurately represented, and that these otherwise unheard stories could be shared, potentially leading to more understanding and acceptance within the profession. In this qualitative study, ten librarians with graduate degrees, who self-identify as autistic, describe their experiences in job seeking and daily working experiences in the library field through interviews in multiple formats.

Anecdotal and first-person accounts indicate that librarianship is a rewarding career for some autistic individuals (Eng, 2017; Spectrum, 2017; Wyss, 2014); however, many autistic librarians have described difficulties in gaining meaningful entry into the field (Lawrence, 2013; Tumlin,

The International Journal of Information, Diversity, \& Inclusion, 5(3), 2021

ISSN 2574-3430, https://jps.library.utoronto.ca/index.php/ijidi

DOI: $10.33137 /$ ijidi.v5i3.36196 
2019). While graduate programs in Library and Information Science/Studies (LIS) prepare students for careers in librarianship, additional barriers may apply for autistic job seekers. These librarians who are otherwise fully prepared through graduate education, are thus often un- or underemployed and prevented from developing as professionals or contributing meaningfully to the field. This study explores this phenomenon in greater detail, letting autistic librarians speak about their own job seeking and daily working experiences.

\section{Literature Review}

Employment rates for autistic adults with average-range IQ are lower than that of the general adult population (Taylor et al., 2015). Despite this, many autistic adults are as able to participate in the workforce as their neurotypical peers. Particularly for autistic adults with advanced degrees, supports needed within the workforce are not those related to intellectual capability to do the work itself, but more often relate to environmental, personal, communicative, and social aspects of the job. A scoping review found that, as described throughout the literature, the better a job "fit" with an individual's abilities, preferences, sensory needs, task demands, and social requirements, the more successful an employment experience would be (Harmuth et al., 2018). Additionally, when the literature described autistic employees as having what may be a "supportive community," including that of managers and coworkers, "they [were] more likely to have a positive employment experience" (Harmuth et al., 2018, p. 36).

Some businesses implement preferential hiring practices for employees with disabilities; Microsoft, for example, has a program that recruits employees with autism specifically (Lu, 2020). But some are wary of these practices, suggesting that they dismiss workplace inclusion and "set a low bar for companies... when (hiring workers with disabilities) should be the norm for all industries" (Lu, 2020, p. 14). Through these programs, autistic workers may find themselves pigeonholed by employers into the types of jobs they are expected to be good at or enjoy. SAP, a global software company, started "Autism at Work" through hiring autistic employees for technology positions. Since that time, they realized that autistic employees "had many skills that were suited to roles beyond tech" and expanded the program to include positions across the company (Lu, 2020, p. 15).

Characteristics of autism manifest differently in every person and "there is nothing about how people with ASD look that sets them apart from other people" (CDC, 2021). As such, autism is often considered an invisible or hidden disability (Hatfield et al., 2017; Neely \& Hunter, 2014). With all disabilities, individuals must often navigate complicated situations in the workplace. For those with invisible or hidden disabilities, issues arise particularly around the topic of disclosure. One systematic review found that some benefits of disclosing for autistic employees include increased acceptance, inclusion, awareness, and opportunity for receiving accommodations, while limitations of disclosing included stigma and discrimination in the workplace (Lindsay et al., 2019).

In librarianship, one study situated in Australia found that job advertisements were more likely than not to include a diversity statement as well as an invitation for applicants with disabilities to apply (Muir et al., 2020). Despite these invitations, many are still hesitant to disclose. A study of academic librarians with disabilities in Canada found that the majority "had not fully disclosed their disabilities at work" and were reluctant to request legal accommodations based on "fear of negative judgments or impacts on their jobs" (Oud, 2019, p. 189). Librarians with hidden or invisible disabilities may be able to "pass" as abled. While "the decision to pass is not always

The International Journal of Information, Diversity, \& Inclusion, 5(3), 2021

ISSN 2574-3430, jps.library.utoronto.ca/index.php/ijidi/index

DOI: $10.33137 /$ ijidi.v5i3.36196 
purposeful," (Hollich, 2020, p. 100), this "passing” is often done through consciously masking characteristics of a disability. However, camouflaging autistic traits to fit in within social situations may have negative consequences for an individual's mental health (Cassidy et al., 2019; Hull et al., 2019). One study found that autistic adults who camouflaged also had more symptoms of depression (Cassidy et al., 2019). As noted by a library researcher with an invisible disability who also studies invisible disabilities, being told that she does "not look disabled," though framed as a compliment, is "incredibly harmful to those with disabilities and is a form of ableism. It reveals an implicit bias that people with disabilities are somehow deficient or subhuman" (George, 2020. p. 110).

In Beyond Accommodations: Creating an Inclusive Workplace for Disabled Library Workers, Schomberg and Highby (2020) suggest that librarians "come out" about their disabilities "...if you feel safe to do so. The more people that you talk about your disability, the more people will have to think about the realities of disabled people" (p. 71). However, this disclosure requires an understanding and inclusive workplace in which an employee with an invisible disability such as autism feels accepted. Despite increases in prevalence and awareness of autism, there are still damaging stereotypes and stigmatizations of what autism is, and the capabilities of autistic people. This is true in the library field as well. Though autism involves a diversity of assignations along a spectrum, and is not always coexistent with intellectual disability, some LIS studies point to shelving as the most appropriate library role (Lund, 2018; Strub \& Stewart, 2010). While shelving is an appropriate position for some, this point of view fails to take into account those who are autistic and have also successfully completed a graduate degree, which prepares them to be able to work in more higher-level roles.

Many negative attitudes about autism and autistic individuals persist. In a recent series of studies, non-autistic adults held "negative implicit attitudes toward autistic adults," which "may help explain why autistic adults report experiences of discrimination" (Dickter et al., 2020, p. 145). Perhaps to avoid this discrimination, many autistic adults find it easier to try and blend in with their peers, as opposed to disclosing that they are autistic. In the U.K., a survey of 111 autistic adults found that only $7 \%$ felt that "society, in general, accepted them as an autistic person," while another 48\% agreed with this statement only "sometimes" (Cage, et al., 2018, p. 477).

Advocates argue that a more accepting, inclusive workplace would remove many of the issues associated with themes of disclosure, accommodations, and camouflaging traits. While autism awareness has become a common phrase, many say work must be done beyond simple awareness, and that autism acceptance is the true goal (Bullus \& Sesterka, 2020).

\section{Methods}

Drawing from the literature, this study seeks to gain a better understanding of the job seeking and workforce experiences of autistic librarians through asking participants the following research questions:

RQ1: How do autistic librarians describe their job seeking experiences?

RQ2: How do autistic librarians describe their daily working environments?

RQ3: What aspects of work in librarianship are appealing to autistic librarians?

The International Journal of Information, Diversity, \& Inclusion, 5(3), 2021

ISSN 2574-3430, jps.library.utoronto.ca/index.php/ijidi/index

DOI: $10.33137 /$ ijidi.v5i3.36196 
A qualitative, phenomenological approach is used to describe the job seeking experiences of librarians with a graduate degree. The idea of "re"presentation of individuals on the autism spectrum is explored by Bakan (2018) as a method in which to present, but not represent, autistic experiences in research. This method is used here to present the experiences of participants in this study through unedited quotes as provided and verified by participants.

This study is based in the social model of disability, which acknowledges all people have differences, and we are disabled largely when presented with environmental and societal barriers that make it such (Oliver, 2013). This does not discount the fact that autistic individuals do indeed have a disability, but instead asks us to understand the potential mismatch and limitations between autistic traits and societal expectations. Additionally, this study is rooted in the principles of universal design, in which products and environments are designed to be more accessible to all (Center for Universal Design, 1997). ${ }^{2}$

\section{Participants}

Librarians with a Master of Library and Information Science (MLIS) or similar degree who resided in the U.S., and identified as autistic, were invited to participate in this study through purposive and snowball sampling methods (Creswell, 2014; Goodman, 1961). Employment status was not a factor for participation. Through a personal network based on multiple years of working at the intersection of autism and libraries, the researcher asked several participants to share the call for participation with their contacts. A recruitment notice was also posted on public facing Facebook sites for librarians interested in neurodiversity or autism. Though these sites were not exclusive to librarians working in any particular locality, the majority of their members did appear to be from the U.S. Recruitment began with the goal of 10 librarian participants. Once ten librarians met the qualifying criteria and chose to participate, the study commenced. Data analysis occurred concurrently with participant interviews to ensure theoretical sufficiency was reached and no additional participants were required. As compensation for their time, all participants were provided with $\$ 40$ gift cards after data collection was complete.

Table 1. Participants

\begin{tabular}{llll}
\hline $\begin{array}{l}\text { Participant } \\
\text { Pseudonym }\end{array}$ & $\begin{array}{l}\text { Type of } \\
\text { Workplace }\end{array}$ & $\begin{array}{l}\text { Title at the Time of } \\
\text { Study }\end{array}$ & Interview Format \\
\hline Abby & Academic & $\begin{array}{l}\text { Electronic Resources } \\
\text { Librarian }\end{array}$ & Text-Based Document \\
Barry & Academic & Business Librarian & Zoom (audio and video) \\
Brent & Public & Public Services Librarian & Text-Based Document \\
Claudia & School Library & School Librarian & Text-Based Document \\
John & Academic & $\begin{array}{l}\text { Distance Services } \\
\text { Librarian (retired) }\end{array}$ & Zoom (audio and video) \\
Max & Academic & $\begin{array}{l}\text { Electronic Resources } \\
\text { Librarian }\end{array}$ & Zoom (audio and video) \\
\hline
\end{tabular}

The International Journal of Information, Diversity, \& Inclusion, 5(3), 2021

ISSN 2574-3430, jps.library.utoronto.ca/index.php/ijidi/index

DOI: $10.33137 /$ ijidi.v5i3.36196 


\begin{tabular}{|c|c|c|c|}
\hline Steph & Public & $\begin{array}{l}\text { Local History } \\
\text { Librarian/Archivist }\end{array}$ & Zoom (audio and video) \\
\hline Susan & Academic & Head of Area Studies & Zoom (audio and video) \\
\hline Thomas & Public & $\begin{array}{l}\text { Children's Services } \\
\text { Librarian }\end{array}$ & Zoom (audio and video) \\
\hline Zachary & Federal Agency & $\begin{array}{l}\text { Library } \\
\text { Technician/Archivist }\end{array}$ & Zoom (audio and video) \\
\hline
\end{tabular}

Note. Table 1 was originally published in Anderson, 2021

\section{Data Collection}

Text Semi-structured interviews were conducted with all participants, though method of participation varied. Based in principles of Universal Design for Learning (UDL), which detail the use of providing options within means of engagement, representation, and action and expression, all participants were given options for responding to interview questions based on individual preference (CAST, 2018). These options included an interview over the phone, an interview using audio and video over the videoconferencing platform Zoom, an interview using Zoom with only text chat (no audio or video), or an interview conducted asynchronously in which the participant responded to questions sent via a written document. Options for communicating are important for inclusive research design; this is particularly true for autistic participants for whom diagnostic criteria includes what the Diagnostic and Statistical Manual of Mental Disorders, 5th Edition (DSM5) refers to as "persistent deficits" in social communication and interaction (American Psychiatric Association, 2013).

Additional accessibility measures were taken based in interviewing best practices, including providing interview questions in advance so that all participants could prepare as necessary. Though every person is unique, many autistic adults appreciate knowing what to expect. In an interview situation, "questions that... they hear for the first time may produce anxiety that could limit their ability to think on the spot, and ultimately limit their ability to respond in a way commensurate with their knowledge and experience" (Whetzel, n.d.). Information provided in advance of an interview helps autistic individuals plan ahead (Randstad, 2021), and also contributes to a more universally accessible process.

\section{Data Analysis}

To make sense of qualitative interview data, this study utilized both the constant comparative approach (Strauss \& Corbin, 1998), as well as a variation of Tesch's (1990) eight-step coding process as utilized through NVIVO, a qualitative analysis software product. To begin the coding process, all transcriptions and original documents were read carefully, and initial notes taken. Three of the most detailed transcriptions were used to establish underlying meaning of "aboutness," or subject matter, with topics listed out. Topics were compared, and similar topics clustered as codes. These codes were then listed into NVIVO. Each interview transcript or original document was then imported into and analyzed in NVIVO, with text segments categorized according to established codes. Particularly descriptive participant responses were coded through the in-vivo process, or using the words of participants in full. Codes were analyzed once

The International Journal of Information, Diversity, \& Inclusion, 5(3), 2021

ISSN 2574-3430, jps.library.utoronto.ca/index.php/ijidi/index

DOI: $10.33137 /$ ijidi.v5i3.36196 
more to determine relationships and resulting themes. Additionally, reflective memos were taken during the data collection process. To establish validity, member checks were conducted with participants at multiple stages of the research process

\section{Findings}

Following the coding process, eight broad themes emerged about autistic librarians' job seeking and workforce experiences:

(1) Disclosure is context-oriented and varies by individual and circumstance;

(2) Barriers, accommodations, and accessibility;

(3) Prioritizing skills;

(4) Helping;

(5) Expectations for managers;

(6) Finding their way into the profession through exposure to libraries;

(7) Finding like-minded people and fitting in; and,

(8) Seeking fulfillment through meaningful work

\section{Disclosure is Context-Oriented}

In both job seeking and daily working life, disclosure was context oriented. Participants largely disclosed information about their autism when receiving cues from their environment which provided a context that it was safe to do so.

\section{Disclosure on the job based on initiative and programming.}

While on the job, some librarians chose to disclose within the context of autism initiatives at their organization, in which librarians wanted to share their own experience and sometimes offer support. As Claudia, a school librarian said:

I definitely made a decision to be more open about my diagnosis when (my) department started using an anti-bullying video that talked about an autistic kid who sat alone during lunch. I wanted the students, and teachers, at my school to put another face to the idea of autism.

Similarly, Steph, a public librarian, has disclosed her status to support programming and services: "if we're doing some kind of autism thing in the library. I'm like, 'okay, look, you got someone on staff who knows a little more than the rest of you because, it's me, I have, I am the thing.'" As Steph described, this has also led to disclosure to some of her regular patrons. One patron learned about her autism "because l've done a presentation on, on, autism at the library and she came to that." Steph found an opportunity to collaborate as this patron "...was working on giving disability education with kids. So we've actually got a rapport because, you know, I can help her with the autism stuff." Susan, an academic librarian, has also disclosed when it related to diversity and inclusion initiatives at her organization: "So I have disclosed, usually in the context of talking about diversity related work or in the context of accommodations in the library."

The International Journal of Information, Diversity, \& Inclusion, 5(3), 2021

ISSN 2574-3430, jps.library.utoronto.ca/index.php/ijidi/index

DOI: $10.33137 /$ ijidi.v5i3.36196 


\section{Disclosure to Provide Context for Behaviors at Work.}

Some librarians described disclosing to provide context to coworkers or supervisors about their mannerisms or behaviors at work. Zachary, an archivist, had a bad experience at a previous teaching position. "I take as much of the guesswork out of that as possible in terms of like, looking for signs or not." As he stated, "I learned that you don't want to be reactive and wait to disclose until after a negative event like a poor performance review." Abby, an academic librarian, had similar thoughts, but noted that she would disclose to her employer after an incident, "if I was receiving poor performance reviews for something that I felt was a result of my autism." John noted that he was pretty open about his autism diagnosis with his coworkers to provide context about his behaviors: "sometimes my coworkers have thought I'm a little bit of a jerk, and a little bit moody. But I wanted people to know that that wasn't their fault. That it's something about me, and it's not them." Max noted that "disclosure gives (my coworkers) a context... for why I act the way I act." He described that he has "certain characteristics that are very much on the spectrum" and disclosing is:

beneficial in the long term, that they have an understanding of this because it gives them a better context for why I am the way I am. I would never not disclose to the people who I work with. It's just a question of time, when do I do it and I want them to get a better sense of who I am as a complete person before I throw a label on myself.

\section{Disclosure While Job Seeking Based on Context.}

Participants also shared whether they felt comfortable disclosing their autism in the job application and interviewing process based on context from the potential employer. As Claudia, the school librarian, said: "if I was applying to, for example, a special education-focused school, then maybe I would consider building my autism into part of my interview." Zachary collected clues about a potential workplace to determine not only if it would be a good fit, but also if he could disclose during interviews. He said he was drawn toward applying at:

Institutions that specifically serve disabled patrons...Or opportunities to contribute that involved disability and accessibility... So like when I attended the interview at the [State] Library. There was a blind interviewer on the panel. They were using a magnifying, magnification device in front of them. And so it was like, oh, you know, here clearly is a disabled person on the panel, and beyond being at a place that was serving disabled people as well. So, you know, it feels like when we talk about disclosure...It's like maybe a place that you feel is safer to disclose or that is more kind of... their outward signals of disability being okay.

\section{Inadvertent Disclosure Based on Work History.}

Others noted that the activism work on their resumes essentially did the disclosing for them as they applied and interviewed for positions. Barry, for example, conducts original research about autism, leading him to disclose more often than before: "once this this line of research opened up, I think it's more advantageous (to disclose). It's like, "why is a random guy doing this research?' Well, there you go. I mean, it makes for a nice narrative." He said that if he was not doing this type of research, "I don't know if I would necessarily tell people. (But) I might." Max does similar work, and said: "In an interview situation...they would definitely know if they look at my CV, because of the research that I do." Steph had been blogging for multiple years about

The International Journal of Information, Diversity, \& Inclusion, 5(3), 2021

ISSN 2574-3430, jps.library.utoronto.ca/index.php/ijidi/index

DOI: $10.33137 /$ ijidi.v5i3.36196 
being an autistic librarian and said "I knew if they Googled me or they look me up on Linkedln, they would see that l've been doing this for a long time."

\section{Barriers, Accommodations, and Accessibility}

Though all participants were employed at the time of interviews, some described barriers in participating in the library workforce related to autism characteristics. As Max stated, he had "challenges with prioritization. My high anxiety. My getting stressed out about ambiguity or becoming overwhelmed very easily or, you know, worrying about saying the wrong thing. Or being very direct or needing a lot of clarification or reassurance." Barry expressed his challenges with organization, expounded perhaps by a co-occurring diagnosis of ADHD: "I use a lot of project management, I use a lot of apps and project management tools and email reminders to basically to keep myself on track. I don't remember stuff... if it's not on my calendar..." Sensory issues in the library were also described by multiple participants, with lighting being a challenge in particular. As Abby described, "In the past when I only had a cubicle and couldn't control the noise or lighting, I felt a constant gnawing level of sensory stress. I also didn't enjoy working in a basement that had no natural light." To address such barriers, some requested accommodations, either formally through a human resources office or by disclosing to and working with a supervisor. Others created their own accommodations.

\section{Creating Their Own Accommodations without Disclosure on the Job}

In many cases, participants created their own accommodations, without requiring disclosure. For example, Max worked with vendors often, and created his own form of accommodation for those interactions:

Having things in writing is really important to me. So because I work with a lot of vendors, they like to be kind of cagey and do things over the phone, and I always ask for them to send it to me in writing, because I have a folder for every vendor I work with and I put the records in the folder.

Multiple librarians also described approaches in controlling the environment to better suit their needs. See Table 2.

Table 2. Creating Accommodations Through Controlling the Environment

\begin{tabular}{ll}
\hline Participant & Representative Quote \\
\hline Zachary & $\begin{array}{l}\text { "One of the things is being able to control the physical environment, } \\
\text { especially sources of sensory stimulation. So if you can adjust the light, } \\
\text { the sound, the temperature. That is always something that can be helpful } \\
\text { to you." }\end{array}$ \\
& $\begin{array}{l}\text { "it was all very loud. Once I got the noise cancelling headphones to } \\
\text { Steph } \\
\text { help...you know, that was like an investment. I was like, at this point, I } \\
\end{array}$ \\
\end{tabular}

The International Journal of Information, Diversity, \& Inclusion, 5(3), 2021

ISSN 2574-3430, jps.library.utoronto.ca/index.php/ijidi/index

DOI: $10.33137 /$ ijidi.v5i3.36196 


\begin{tabular}{|c|c|}
\hline Susan & $\begin{array}{l}\text { "It's an old 60s building with these terrible lights overhead. And it was } \\
\text { giving me headaches. Daily, daily headaches. I was miserable. I could not } \\
\text { barely function in that office. And so I had come up with all these things } \\
\text { where I would like, cover it. I would just work with the lights off." }\end{array}$ \\
\hline Claudia & $\begin{array}{l}\text { "Being able to dim the lights in the library is my most used } \\
\text { accommodation. I have high-fidelity ear plugs that I use when things get } \\
\text { too loud, but the library is typically not that noisy." }\end{array}$ \\
\hline
\end{tabular}

\section{Creating Their Own Accommodations without Disclosure While Job Seeking}

Multiple participants noted they benefited from getting interview questions in advance, a strategy that did not necessarily require disclosure. As Abby described, "I always appreciated it when I was given a copy of the interview questions just before the interview so I could concentrate on my answers instead of trying to remember what was asked." Max asked for this without disclosing: "I remember for a job that I got, I actually asked for, for the questions ahead of time and they sent them to me. That is something that I would definitely recommend." Zachary agreed that questions in advance helped, but they needed to be sent well in advance: "So I appreciate when I get the questions in advance... (but) I had an experience where they sent me a general idea. And then it was like an hour or so before the interview, they sent you more specific questions." Zachary did not do well in that circumstance, and followed up with the interviewer, telling him "I understand what you were trying to do was nice, but that made me panic, like you sent me this list, an hour before our interview and that left me feeling like I was scrambling." As Zachary explained:

They hadn't thought that that would be an anxiety inducing thing. I didn't, I didn't understand that perspective, because I'm like, you know, I tried to be as prepared as much as possible. And if you send me specific questions, I'm going to be trying to be prepared for those questions. And if I see a question that I don't feel like I can answer very well, I'm going to be thinking about that, you know, beforehand and during the interview.

Some created their own systems for preparation. Abby noted that "The phone interview can be stressful because you have to answer questions on the spot. For autistic people, thinking quickly under pressure can be difficult." She "found it helpful to write down my answers to questions I anticipate being asked." Similarly, Claudia "created a list of potential interview questions (based on experiences from other school librarians), and wrote out answers, and practiced them.

Abby created a "mental script" for interview dinners, and while she was able to do so, she considered it exhausting:

Interview dinners or lunches can be stressful because you have to make small talk, which generally requires a great deal of forethought for an autistic person. I have developed enough skills to know how to navigate this without too much trouble, but it can be very exhausting to have to consult a mental script of conversation rules in an interview scenario, while trying to appear casual and relaxed.

The International Journal of Information, Diversity, \& Inclusion, 5(3), 2021

ISSN 2574-3430, jps.library.utoronto.ca/index.php/ijidi/index

DOI: $10.33137 /$ ijidi.v5i3.36196 


\section{Masking}

During the job seeking process, most participants chose not to disclose at all, instead resorting to their own coping strategies such as masking their autism characteristics. Claudia said that interviews were "consistently terrifying," and that "I dress up in clothes that look nice (but aren't always the most comfortable), put on makeup (which can be a big sensory issue if the room gets too hot), and pretend to be an upstanding, 'normal' person." Abby considered herself "...fortunate because I am able to muster the acting skills needed to be successful at interviews," but also noted that most academic job interviews "require an entire day or more of public performance and socializing with new people that can be overwhelming and exhausting for autistics."

Susan described masking, and its aftereffects, during the academic job interview:

Can I just go hide in a tree for like 10 minutes and then I can put the smile back on and we can do this again? Um, so it's just a lot. It's a lot of socializing and I don't I don't really mind it while I'm doing it. Because I'm running on just like intense adrenaline. But by the time I'm done, like, I, I...I don't have meltdowns much anymore. But when I come out of those, it feels a little like a post-meltdown where like, I can't quite get my eyes to focus. There's a lot of, like, physical, like, sensory stuff.

John noted that masking during an interview could actually be detrimental to a librarian once they are on the job: "I think they should just be genuine. Because if they're genuine and they show people who they are, and they behave in the manner in which they behave, they have a better chance of getting hired by accepting people." As he said, "if they hide who they are and then show up in there a completely different person, people would not be happy with that." However, not all librarians felt able to disclose for accommodations during the job seeking process. As Claudia stated: "I have heard a lot of negative stories from other autistic professionals and disabled librarians, who worry that interview committees use things like autism and disability to filter out candidates during the selection process." She noted that "the interview doesn't provide enough time for me to succinctly explain why my autism makes me a better librarian (for some aspects of the job), not a worse one."

\section{Requesting Accommodations}

Though many participants described implementing strategies they enacted themselves, some disclosed to HR or their supervisors for accommodations. Some did so after a barrier or issue arose. In the previous example, Susan initially attempted to control the lighting herself, but ended up also letting HR know. "I was like, wait a minute, I'm not gonna buy a couple of lamps until I point out to HR that I have to ... because there's no accommodation for this." Claudia, similarly, "...disclosed to my principal after I started feeling overwhelmed by some unexpected changes to my daily routine."

Steph noted that she disclosed for informal accommodations from her supervisor. "I know I take instructions better in writing because of too much information to share with me at once. It'll just kind of overwhelm me. So sometimes I mention that, like, "please give me this in writing it would help me to remember it." She also asked for more support to understand social norms during meetings with other department heads:

The International Journal of Information, Diversity, \& Inclusion, 5(3), 2021

ISSN 2574-3430, jps.library.utoronto.ca/index.php/ijidi/index

DOI: $10.33137 /$ ijidi.v5i3.36196 
So I go to these [meetings], and l've actually, you know, been working with my supervisor to be like, okay, when do I speak? When do I not speak? Is this a good time for me to cut in? How do I know when it's okay to share my thoughts on something without, you know, making it seem like I'm trying to interrupt her...Is this like, too personal or outside of work? Should I not talk about this? And it's been helping.

Breaks, or spaces to step away, were also described as helpful accommodations. Barry said that he has never asked for formal accommodations but might consider asking HR about the option of working from home occasionally when he had large amounts of reading to get done because he said he has "trouble filtering out noise." Study rooms for faculty could also be an option, he said:

If I could just hide and no one knew where I was for a couple hours. That would be great. No email, no nothing. It would be great if there were somewhere I could go and just really concentrate. I just have, I have so much trouble concentrating. Even with all the systems I have to manage my workflow.

For Zachary, it was important to have paperwork on file while in graduate school even before asking for accommodations or any barriers arose. "I wanted my paperwork on file in case I did need to request any accommodations, that all of that would be taken care of and ready to go." However, this is not something he has ever done at a job, though he says "I do identify as disabled when form CC-305 is presented to me when applying. I have known disabled people who do not even do that." Susan discussed the idea of disclosure, but said "quite frankly, l'd rather have us be working on making it safer for people to disclose before pushing people to do it. And I'm not convinced that it safe. Just like with a lot of things that are hidden."

\section{Prioritizing Skills and Strengths}

Participants described the importance of being allowed to demonstrate librarian skills during job interviews in lieu of performative social acts. This was also reflected in on-the-job experiences, in which librarians described how it is important to build on an autistic employee's skills, rather than trying to improve or even force areas in which they are less confident or comfortable.

\section{Skills Versus Social Norms During Interviews}

Multiple participants described the interview process as tough, as they had to navigate social norms rather than simply demonstrate their skills. As Steph described, "I would leave interviews and, like, 'oh, they, they think I'm just average. Like I can, I can do the job. But like, I'm not good at talking parts. So I don't know how they're gonna view me." Steph worked with a job coach to practice interviewing norms:

Eye contact is obviously hard, (so) I would do the trick where I would look at people's noses or mouse instead...I was probably very awkward and stiff at interviews, because I was so nervous and I just didn't have that, you know, ability to just be gregarious and have rapport with people.

As some participants described, though, it should not be the soft skills that are judged at an interview, but instead their professional skills and knowledge. As Max stated about academic library job interviews:

The International Journal of Information, Diversity, \& Inclusion, 5(3), 2021

ISSN 2574-3430, jps.library.utoronto.ca/index.php/ijidi/index

DOI: $10.33137 /$ ijidi.v5i3.36196 
There's the dinners and the lunches with the search committee and you have to make small talk. And you know you're being judged on that. And if you can't make small talk, if you can't have those social skills... you could have all the knowledge and talent in the world, but if you can't, you know, meet those expectations, socially, then you could be excluded. And that's sad to me. That's unfortunate.

As he said, the interview "shouldn't be a popularity contest. It should be about your competency and your ability to do the job. I think that that should be a part of the interview process is actually being able to demonstrate what you know." John said he excelled in the "skills" portion of his job interviews: "I think the skills portion is something that that I interviewed really well about; what I could do for people and, you know, the type of skills I would be bringing to an organization." Similarly, Susan said that the best interview she ever did was when she was able to demonstrate her knowledge: "That was probably the calmest l've ever felt. I went in that presentation and I remember telling them stuff that I knew."

\section{Strengths On-the-Job}

Participants in this study explained that autistic people are not all the same, but instead have individual strengths as librarians. They stressed the importance of "playing to these strengths" in their jobs and being given the opportunity to focus on strengths in the workplace. As Steph described, she wanted to have a boss who was "understanding that I'm, you know, I'm on the spectrum and that I, you know, there's certain things I'm going to be good at, (and) certain things I'm not going to be good at." Abby also said it was important for supervisors to "focus on your (autistic) librarian's strengths! I am the designated note-taker for my district librarian group, because my short-term memory skills allow me to hold a lot of dialogue in my head at once." Barry noted an individual strength of problem solving, and said it might be a strength shared by other autistics:

I think we're really, many of us are really, are really great at problem solving and coming up with solutions without necessarily thinking about politics or, you know, what is the Faculty Senate going to say, what is the Provost going to say. At least that's my, that's been my experience.

Information seeking was described as a strength by both John and Claudia. John described a particularly tough information seeking experience that he found rewarding: "one of the hardest topics I ever had was urban farming in Denver. That was really, really hard. It took hours and hours of research so that I could make a phone call that lasted 10 minutes." Similarly, Claudia noted that she was "very good at finding resources" and that her "colleagues always cheer when I do things like this, because it makes their jobs easier for them." Other participants described positive traits related to their autism as including creativity, honesty, and loyalty. Thomas hypothesized on the possibility that Melvil Dewey was perhaps autistic, due to his strengths in classification:

as much as l'd love to blow up the Dewey Decimal System and all the foundations of the profession that Dewey started, Dewey was very likely an Autistic...Only an Autistic person would think that way... The profession, itself, is likely a product of the Autistic mind.

Thomas offered this while reflecting that, "alongside the challenges that Autistic library workers may face, is the strengths that they can also bring."

The International Journal of Information, Diversity, \& Inclusion, 5(3), 2021

ISSN 2574-3430, jps.library.utoronto.ca/index.php/ijidi/index

DOI: $10.33137 /$ ijidi.v5i3.36196 


\section{Finding Strength in Routine}

Librarians appreciated routine in the daily working environment, though that routine varied person to person. What mattered was that it was their personal routine, something they were prepared to face.

Claudia noted that the most rewarding part of her job was the social aspect, but even that followed a routine:

I like helping people, and when people come to the library for help, they usually follow the same basic routines. It's easy for me to find what they need, and it makes me feel so useful...For someone who struggles a lot socially, and doesn't have a lot of friends, being able to interact with people, and have a positive effect on their lives, while following a very clear routine, is incredibly rewarding.

Claudia also disclosed her autism after experiencing changes to her routine and needing accommodations.

A shake-up to their routines made completing daily tasks more challenging for other participants as well. Steph, for example, described difficulties in navigating "non-routine communication" on the reference desk when she was asked to cover those shifts. And Claudia said that for autistic librarians, "Non-routine social interactions, especially those that are focused on a conflict, should either not be required, or should be a team effort."

One librarian, Max, was more established in his career, and noted that the longer he worked, the more willing and able he was to work through changes. And it should be pointed out that daily routines are just one aspect; many librarians in this study were willing to, or already had, accepted greater responsibilities and changes to their schedule. Additionally, one librarian, Karen, actually appreciated that her more administrative job included many different things every day.

\section{Viewing Strengths as Unique}

Many participants worked in public services, interacting with students or patrons regularly; multiple participants described these as "unique within autism" strengths.

John said he thought autistic librarians "can be, I think very good at certain types of tasks such as web design. Or, maybe even cataloging. Those types of things." Then he reflected that those were not his strengths, and was not reflective of his own position, saying "maybe not so much the type of position that I was in." Barry also reflected on this idea:

I don't know who else is doing what I'm doing. I'm sure there are plenty of people, but I don't know who they are. And so I feel kind of isolated, you know. I'm not working in cataloging; I'm not shelving books or something, doing something really repetitive.

Thomas, a children's librarian, echoed such statements:

I think a lot of autistic people go into libraries, because they think it's going to be a quiet place, and it's not, So I think that there are some autistic people, that maybe a public library wouldn't be the best place for them. I think that there's a lot of misconceptions

The International Journal of Information, Diversity, \& Inclusion, 5(3), 2021

ISSN 2574-3430, jps.library.utoronto.ca/index.php/ijidi/index

DOI: $10.33137 /$ ijidi.v5i3.36196 
about what a library is. Like, I think that it's worked for me, because I'm not really like a typical, like, I'm not typical, I think in my desire to interact with people. Although I don't know.

As Barry, who regularly interacts with students and faculty, summed up, "I'm not supposed to be, I'm not supposed to be good at my job. I'm supposed to be terrible, if you look at the stereotypes and everything and the classical characteristics. But somehow I do it."

\section{Helping}

All but two participants used a similar statement to "I want to help people" when describing their career in libraries. They entered the profession to help people, and they found value in their daily jobs helping people. See Table 3 for a selection of representative quotes.

Table 3. Helping Through Library Roles

\begin{tabular}{ll}
\hline Participant & Representative Quote \\
\hline Claudia & “I like helping people, and when people \\
come to the library for help, they usually \\
follow the same basic routines. It's easy \\
for me to find what they need, and it \\
makes me feel so useful." \\
“The thing I find most rewarding is the \\
enjoyment of finding information for \\
people because it makes me feel \\
competent and valued." \\
“I really like helping students and my \\
patrons." \\
“I learned that a person could combine \\
their interests in reading and learning \\
into a career where you could help other \\
people." \\
Yeah, so with history stuff, it's, when I \\
can help somebody find something \\
they've been looking for for a long time. \\
That feels good." \\
"The most rewarding part (of \\
librarianship) was helping people. And I \\
noticed it when I was cleaning out my \\
office, all the cards I would get from \\
students saying 'thank you for helping \\
me,' and they were really, really \\
wonderful.
\end{tabular}

The International Journal of Information, Diversity, \& Inclusion, 5(3), 2021

ISSN 2574-3430, jps.library.utoronto.ca/index.php/ijidi/index

DOI: $10.33137 /$ ijidi.v5i3.36196 


\begin{tabular}{|c|c|}
\hline Max & $\begin{array}{l}\text { "Being a librarian gives me the ability to } \\
\text { be surrounded by information, help } \\
\text { people and also be in higher ed, which I } \\
\text { really like." }\end{array}$ \\
\hline Thomas & $\begin{array}{l}\text { "I do like, I like, I like helping people. } \\
\text { And that's what I like about it, I like } \\
\text { feeling like I'm actually helping people, } \\
\text { like actually helping people find books to } \\
\text { read or making suggestions or, you know, } \\
\text { the programs. The library programs I'm } \\
\text { doing, like, you know, that they actually } \\
\text { mean something..." }\end{array}$ \\
\hline
\end{tabular}

\section{Expectations for Managers}

Two categories emerged of what participants expected from potential or current employers. First, participants wanted hiring managers or interviewers to have at least some prior knowledge of autism or disability. Additionally, they expected clear feedback. Brent described a positive interviewing experience due to his supervisor's prior knowledge of autism: "My interview at what would be the library that I work now...went well. My former supervisor had experience serving people on the spectrum. He was not put off by the nervousness I demonstrated. He also fully listened to me."

Participants wanted to hear from hiring bodies after their interviews, even if they did not get the job. Zachary described the frustration of not knowing why he was not offered positions after interviews: "I've been trying to ask for feedback after the interviews...A lot of times they don't provide you any feedback at all. Which, 'why should I have to ask you for feedback?' is a whole other thing."

Librarians also valued clear and honest communication from their supervisors, though some pointed out that this feedback still needed to be provided in a thoughtful manner. They valued feedback in general, from praise to constructive criticism. See Table 4.

Table 4. Supervisor Feedback

\begin{tabular}{ll}
\hline Participant & Representative Quote \\
\hline Zachary & $\begin{array}{l}\text { "one of the big things for me is communication. Making } \\
\text { it clear that I need, like, explicit communication or, you } \\
\text { know, just in general, I may need more in the way of } \\
\text { communication. that's my, probably, biggest } \\
\text { accommodation." } \\
\text { "be very clear with your expectations!" } \\
\text { Claudia } \\
\text { Steph }\end{array} \quad \begin{array}{l}\text { I had trouble with (previous jobs) because they were } \\
\text { kind out of my scope of what l'd studied, and they }\end{array}$ \\
\hline
\end{tabular}

The International Journal of Information, Diversity, \& Inclusion, 5(3), 2021

ISSN 2574-3430, jps.library.utoronto.ca/index.php/ijidi/index

DOI: $10.33137 /$ ijidi.v5i3.36196 


\begin{tabular}{|c|c|}
\hline & $\begin{array}{l}\text { were also, were asking things of me that they weren't } \\
\text { really explaining. And maybe if I was not autistic, I } \\
\text { would have understood what they wanted, but they } \\
\text { were not clear with me... it was really, there was, like, } \\
\text { a big communication gap. }\end{array}$ \\
\hline Max & $\begin{array}{l}\text { "I really truly appreciate feedback on how I can } \\
\text { improve. I really like that. I am never defensive about } \\
\text { it. And my boss knows that she can tell me anything. I } \\
\text { take it, you know, the way it was intended, which is to } \\
\text { be helpful." }\end{array}$ \\
\hline Barry & $\begin{array}{l}\text { "I mean, unless they're just doing a really awful things } \\
\text { that the organization can't come back from just say, } \\
\text { just take them aside. Don't embarrass them in front of } \\
\text { their colleagues, that's awful." }\end{array}$ \\
\hline Abby & $\begin{array}{l}\text { "Some autistic people prefer clear, direct feedback, } \\
\text { while others are very sensitive and need a more } \\
\text { nuanced approach." }\end{array}$ \\
\hline Claudia & $\begin{array}{l}\text { "it helps so much to be explicitly told that I'm helping, } \\
\text { and that I'm appreciated. I think that kind of positive } \\
\text { feedback could be really good for any librarian." }\end{array}$ \\
\hline
\end{tabular}

\section{Finding Their Way into The Profession Through Exposure to Libraries}

Many found their path in librarianship by being library users themselves. For example, when John worked in retail, he used his public library to check out travel videos, giving him an opportunity to see the world. He described how this is what inspired him to help others and enter the field. Claudia found libraries to be a "place of respite" as she was growing up: "Libraries were often quiet, and even when they weren't, they were a place where I could lose myself in books and computers. I also really liked the organization and order of the library stacks." Brent echoed a similar statement: "As a child, I loved going to the library as it was a quiet place with books. I was also interested in obtaining information as a child." Max described being a lifelong user of libraries, with parents who brought him to the library as a child: "I had mentors in public libraries when I was a kid. I remember a children's librarian, and then adult services librarians, who I looked up to, some of whom I keep in contact with today." As he said, "that's part of what drew me to (librarianship), and I just love information." As Max went to college, he also had "a really positive undergraduate library experience" in which "I would recommend books and they would purchase most of them. And I just spent a lot of time in the library. And it was a positive environment. I had a lot of mentors that were librarians there." Susan also reflected on childhood exposure to libraries:

I do have sort of the typical librarian, like, 'grew up loving reading personality.' Like my first, one of my first jobs out of college was in a bookstore and so I definitely was drawn to, to just that sort of ethos of librarianship, right. I loved libraries as a kid.

The International Journal of Information, Diversity, \& Inclusion, 5(3), 2021

ISSN 2574-3430, jps.library.utoronto.ca/index.php/ijidi/index

DOI: $10.33137 /$ ijidi.v5i3.36196 


\section{Finding Like-Minded People and Fitting In}

Most participants in this study appreciated their fellow librarians, saying that they fit in with this bunch of people as a whole. As Zachary said, "You know, I feel like I fit in in this world, generally, and that it's rewarding to work with people that you know you have things in common with." Abby described an experience of her first position in libraries:

Within the first few weeks I realized it was the first place I had worked where I felt like I had not only found 'my tribe,' but I also loved the work itself. I lost track of time as I became immersed in the details, facts, and processes related to processing archival material. I also had so much in common with librarians and archivists. Everyone seemed to be pleasant, quirky introverts with special interests that ranged from anime to knitting. Being a 'nerd' was normal.

Though many described fellow librarians in positive terms and felt loyal to those who accepted and accommodated them, this is not to say that there were not also some challenges in working with their peers or supervisors. John, recently retired, stated: "We have some real jerks working at the place that I worked at," and said that he also worked under a dean who denied that neurodiversity existed.

\section{Seeking Fulfillment Through Meaningful Work}

Multiple participants described starting in other careers, and then moving to the field of librarianship after not feeling fulfilled professionally. As Barry described, "I worked in the retail industry for quite a, quite a while, but I knew that was never going to be enough for me." He described that he would never be happy there because "the level of questions were just not satisfactory to me. And so I wanted to find, I, you know, I wanted to find something that had a bit more meat on the bones." John described a similar experience: "[B]efore I became a librarian. I was working for a large corporation and I made a lot of money for them. But there wasn't, I didn't feel like I was doing society or people any good." Thomas described a series of office jobs after working through AmeriCorps: "I was just working in an office and, you know...like, it was just not meaningful work and I was interested in librarianship much more as the public service aspect of it." Participants in this study pursued librarianship as a potentially more fulfilling career option.

Steph described her work in archives at the public library as meaningful: “...that means so much to me like just, you know, to protect this information and these documents...Just to know that I am making that safe so that someone else can use it later." Steph gets emails from library patrons thanking her for these documents and said, "it means a lot to the people when they do see it, like, that just is so fulfilling and, like, I get very emotional." Max said, "I really love what I do. I feel really fortunate to have this and I find it meaningful." He noted that his work in e-resources was perhaps even more important during the lockdown period of the COVID-19 pandemic when patrons might not have access to physical collections: "I feel like l've had a real impact on people's ability to access information that they need to be successful in their teaching, learning and research." Thomas described his impact as a children's librarian as powerful: "I can have an impact on what somebody is reading and, like, that, to me is a is a very powerful thing" and noted that it was rewarding "just knowing that people appreciate what you do."

The International Journal of Information, Diversity, \& Inclusion, 5(3), 2021

ISSN 2574-3430, jps.library.utoronto.ca/index.php/ijidi/index

DOI: $10.33137 /$ ijidi.v5i3.36196 


\section{Discussion}

Findings indicate that autistic librarians enter the profession based on previous exposure to libraries, as well as believing the librarian role to be fulfilling. However, there are barriers within job seeking and workforce experiences for which some autistic librarians disclose and request accommodations, though most have developed individual coping or preparation strategies. Issues of disclosure are threaded throughout individual themes, reinforcing the idea that, while workplaces should strive toward greater understanding and acceptance of autistic employees, they should also create processes that are more universally accessible without requiring individual disclosure. The following discussion addresses such themes as they pertain to the study's guiding research questions.

\section{How Do Autistic Librarians Describe Their Job Seeking Experiences?}

Some librarians in this study thrived when they could prepare in advance of their job interviews. By providing all candidates with interview questions in advance, they will be able to prepare more thoughtful, comprehensive answers. Advanced preparation also helped one librarian do what she said was her best interview ever, simply because she had a lot of knowledge and experience in the area. She was prepared for the interview. This also speaks to the need for placing more emphasis on asking candidates to demonstrate skills and knowledge during the job interview, taking some of the focus away from social expectations.

Questions around disclosure were perhaps the largest barrier identified. By and large, participants in this study chose not to disclose their autism during the job seeking process. There were few exceptions, and these disclosures typically came when a resume essentially disclosed for them, or after an initial job offer was received. Multiple participants described how their CV or resume could essentially "out" them during the job seeking process; while some were active in advocacy work, others were simply interested enough in their own autism diagnosis to pursue autism as a focused research and/or service topic. Multiple librarians did find comfort in applying to jobs with outward facing indicators of disability and/or autism acceptance, though still were not prepared to disclose during those applications or interviews. Disclosure carries a real risk. While discrimination is generally illegal under the provisions of laws or federal acts, such as through Title 1 of the Americans with Disabilities Act (ADA) in the U.S., librarians may be discriminated against based on a hiring manager's lack of knowledge or biases about autism. One analysis found that hiring discrimination most often occurred for interviewees with either physical or sensory impairments, the latter of which autism is included (McMahon et al., 2008).

The library job market is competitive as it stands; predicted "graying of the profession" trends never came to fruition, and library school graduates face tough competition for entry level jobs (Ewell, 2012). Academic librarian interviews can be particularly grueling, with social events and professional demonstrations stretched over the course of one or multiple days. Autistic individuals face even greater stresses, being met with internal questions of disclosure and adhering to social norms perhaps tangentially related to skills they need for the job. Building in universal accommodations could reduce some of these barriers and give autistic candidates an equal chance at employment.

The International Journal of Information, Diversity, \& Inclusion, 5(3), 2021

ISSN 2574-3430, jps.library.utoronto.ca/index.php/ijidi/index

DOI: $10.33137 /$ ijidi.v5i3.36196 


\section{How Do Autistic Librarians Describe Their Daily Working Environments?}

Strub and Stewart (2010) posit that autistics appreciate repetitive tasks and so are well-suited for shelving. Though, of course, this kind of work may appeal to some, it is a gross oversimplification of the abilities all autistic library employees may have. Autism is just one facet of a person's identity, and autistic librarians in this study reflected many varied interests and professional strengths. While shared characteristics of autism did emerge throughout some responses, more often characteristics, preferences, and need for support or accommodations varied widely. This study, though small, supports the idea that librarianship is a good fit for some autistic individuals, but maybe not for the stereotypical reasons as discussed in the literature review of this article. Instead, autistic librarians in this study care deeply about working with people they feel a kinship with, channeling their strengths in the workforce, and helping the library patrons they serve.

Participants identified particular strengths they brought to the workforce, though those strengths varied by individual. It is important for both employees and employers to recognize such strengths and to focus on them, allowing individuals to thrive in their roles. Rather than assume all autistic employees will thrive in one area, employers should instead provide opportunities in a wide variety of roles, as strengths and interests differ among autistic adults (Lu, 2020). Additionally, participants noted that they were better and more comfortable in their jobs when employers allowed them to shine in their area of expertise rather than filling in for others or being given tasks designed to make them stretch.

Within public facing roles, librarians did describe certain things that made their jobs easier or more challenging. For example, routine was still appreciated, but it did not necessarily need to look like the stereotyped repetition that is sometimes ascribed to autistic individuals. Instead, these librarians appreciated a daily routine, knowing what to expect in their workdays. For example, one librarian did not want work time in the back office, away from the public. Though valued by others, this librarian said he would not know what to do with his time in the office as it was a change from his normal working routine.

Librarians in this study viewed their strengths and roles as unique, and this was especially true for those who worked in public services. Even with participants emphasizing that every autistic person manifests characteristics differently, many still repeated stereotypes of autistics only wanting to work behind the scenes, and their experiences enjoying working with people as singular. Results from this study indicate that autistic librarians are just as likely to enjoy working in public services as working behind the scenes. The feelings many participants had of unique strengths demonstrates that there needs to be a stronger network and more visibility of autistic librarians in the library profession. This would allow current and potential librarians to build a community of support and provide a glimpse into librarianship for autistic individuals considering this as a career path.

\section{What Aspects of Work in Librarianship are Appealing to Autistic Librarians?}

Previous studies indicate that some autistic individuals consider the library to be a welcoming space, leading to an interest in librarianship as a career (Eng, 2017; Lawrence, 2013); this idea is supported by the findings in this study. Participants in this study largely found their way into the library field through exposure to libraries as a user or patron. Autistic librarians in this study were also interested in the field because they felt it was more fulfilling than some other career

The International Journal of Information, Diversity, \& Inclusion, 5(3), 2021

ISSN 2574-3430, jps.library.utoronto.ca/index.php/ijidi/index

DOI: $10.33137 /$ ijidi.v5i3.36196 
paths. Multiple participants began in business, retail, or office jobs, and felt that a shift to libraries would be more rewarding. Participants here did not want just a job. Instead, they wanted a career that would also give them a sense of purpose.

No matter the role, nearly all participants indicated that they appreciated that their jobs helped people-whether through access to information or otherwise. This is an important finding, and one that contradicts a commonly held negative stereotype that autistic individuals lack empathy. Indeed, for these participants the opposite is true.

Librarians have a responsibility to take this information and create more opportunities for what is an un- and underemployed demographic group. In creating more accessible and accepting library spaces for autistic youth, teens, and adults, libraries can continue to be a welcoming and nurturing environment for autistic individuals, potentially encouraging similar career trajectories as those described here.

\section{Implications for Practice}

Characteristics of autism manifest differently in every person, and it is not fair to make blanket statements that all autistic people are the same. However, some common manifestations of autism were confirmed within the findings of this study and provide us with some knowledge of how to create more accessible interviewing and working environments. For example, routine is appreciated, though it may look different person to person. Options for communication are valued, including providing written documents along with verbal conversations. Opportunities to prepare in advance for situations such as meetings can be helpful and reduce stress. Clear and honest communication is necessary, and supervisors should be clear about expectations and direct in feedback.

In the workplace, a lack of knowledge about disabilities is one of the largest barriers for acceptance of coworkers with disabilities (Vornholt et al., 2013). Training and education are critical for librarians to better understand their autistic peers, employers, and employees. Librarians in this study felt more comfortable applying at organizations that showed outward signs of autism and disability knowledge and acceptance, and more comfortable disclosing at work when provided context that it was safe to do so. An autism-educated staff will also lead to more accepting spaces for autistic library patrons, some of whom, such as many participants in this study, might translate those positive feelings into a career path in the field. It should not be the responsibility of autistic librarians to do this baseline work. Instead, all library administrators should ensure their staff members have baseline knowledge of autism so autistic patrons and employees feel welcomed into a more accepting and accessible environment.

Until universal autism education and training occurs, the burden should not be on autistic librarians to disclose their status. Instead, processes should be made more universally accessible so that their interview and workforce experiences are no different from that of a neurotypical peer. By building in simple accommodations for all, autistic interviewees may have the ability to demonstrate their ability to do the job, not their ability to navigate social expectations of an interview. By providing all candidates with tools for advanced preparation, such as sending interview questions and schedules in advance, disclosure to receive those tools would be unnecessary. Similarly, accommodations may be made in the library that benefit all employees, without requiring disclosure. Participants in this study noted options for controlling the physical and sensory environment and work shifts; library managers should consider options such as

The International Journal of Information, Diversity, \& Inclusion, 5(3), 2021

ISSN 2574-3430, jps.library.utoronto.ca/index.php/ijidi/index

DOI: $10.33137 /$ ijidi.v5i3.36196 
adjustable lighting, flexible scheduling options, and allowing work from home or distraction-free study spaces as part of a schedule.

Giving job candidates the opportunity to talk about or demonstrate knowledge and skills directly relevant to the jobs they apply for will also benefit all. In doing so, employers will get a glimpse into a potential employee's workplace capabilities, and candidates can demonstrate their onthe-job skills. While on the job, employees should be allowed to focus on their areas of expertise. "Other duties as apply" is commonly listed for librarian job ads; while this might be necessary in some instances, autistic librarians appreciate both routine and being able to demonstrate their individual skills and knowledge. Library managers should allow librarians, whenever possible, to work in their areas of expertise.

This study avoids using problematic deficit-based language (e. g., "suffers from"). But it would be naïve to gloss over the truth that there are additional barriers in the job seeking process and daily work experiences for autistic librarians, one of whom said she was glad this paper would share their "struggles." In a world constructed around neurotypical structures, barriers do exist. And autistic librarians should not have to choose between masking their characteristics and exhausting their mental resources or disclosing in a potentially hostile environment. By acknowledging this and creating more accessible work environments, autistic librarians will have a fairer chance of participating in the workforce through a fulfilling career.

Many opportunities exist for future work in this area. Library staff and librarians without a professional/master's degree in library and information science (MLIS) were not included in these interviews, and expanding this work to include their voices could bring additional perspectives to employment experiences. This study only explored experiences of librarians within the U.S. Additional work might compare commonalities and differences for autistic adults in the library field internationally. This study implemented inclusive measures that may be used as a baseline for research with autistic adults, with future work incorporating more inclusive practices as funding and research supports allow. Suggestions for autism inclusive research practices include building in accessible options and providing clear and explicit instructions, engaging with participants at the level they wish to be involved and compensating them appropriately, building mutual respect, working to address a true need, and avoiding assumptions (Anderson, 2021).

Building from this study to include all librarians with invisible disabilities might also reveal common themes around issues of disclosure and more. Perhaps the most impactful work that could be done next involves library administrators and hiring managers. Individuals in these roles should be provided with training and education about accepting and supporting autistic employees, with their knowledge and attitudes about such employees measured after training

\section{Conclusions}

Librarianship is an appealing career for some autistic adults, a significantly un- and underemployed population. While autistic librarians face additional barriers when entering the workforce, those who find employment find their careers to be largely rewarding. Results from this study indicate that some of many job-seeking and daily workforce barriers could be removed through implementation of more inclusive practices.

Focusing on skills, allowing individuals to prepare in advance, developing a more autism-informed workplace, providing clear and honest feedback, and allowing for flexible, adjustable workplace

The International Journal of Information, Diversity, \& Inclusion, 5(3), 2021

ISSN 2574-3430, jps.library.utoronto.ca/index.php/ijidi/index

DOI: $10.33137 /$ ijidi.v5i3.36196 
environments are all strategies that would make job interviews and the workplace more accessible for all. By making such adjustments, all applicants and employees have the potential to benefit, without requiring individual disclosure. Countless librarians likely do not disclose, so the true number of autistic librarians is unknown. By highlighting the experiences of the ten participants in this study, autistic librarians can understand that they are part of a larger, though perhaps hidden, community. For those who feel alone on their employment journey, this information is priceless.

\section{Endnotes}

${ }^{1}$ Identity-first language (e.g., "autistic") instead of person-first language (e.g. "person with autism") is used deliberately throughout this paper. While there is not a clear consensus in the literature (Botha et al., 2021), identity-first language includes the most agreed upon terms by autistic people themselves (Bury et al., 2020). Person-first language, while viewed by some researchers as the most respectful terminology, is largely viewed by autistic people as offensive (Bury et al., 2020; Kapp et al., 2013; Kenny et al., 2006).

2 This paper presents the thematic findings from interviews held with librarians with implications drawn largely for library practitioners. A more detailed description of the methodology used to procure these findings, with implications for inclusive research, can be found in Anderson's (2021) article "Exploring the Workforce Experiences of Autistic Librarians through Accessible and Participatory Approaches."

\section{Acknowledgements}

This research was supported by a Summer Research Fellowship Program Grant from the Office of Research at Old Dominion University, Norfolk, Virginia, USA.

To acknowledge and support the work done by autism self-advocates, readers of this paper are asked to consider supporting the Autistic Self Advocacy Network (ASAN). Donations can be given on their website at www.autisticadvocacy.org.

\section{References}

American Library Association. (2019, January). Core values of librarianship. Issues \& Advocacy. http://www.ala.org/advocacy/intfreedom/corevalues

American Psychiatric Association. (2013). Diagnostic and statistical manual of mental disorders. 5th ed. American Psychiatric Association.

Anderson, A.M. (2021). Exploring the workforce experiences of autistic librarians through accessible and participatory approaches. Library and Information Science Research, 43(2). https://doi.org/10.1016/j.lisr.2021.101088

The International Journal of Information, Diversity, \& Inclusion, 5(3), 2021

ISSN 2574-3430, jps.library.utoronto.ca/index.php/ijidi/index

DOI: $10.33137 /$ ijidi.v5i3.36196 
Autistic Self Advocacy Network (ASAN). (2021). About autism. About ASAN. https://autisticadvocacy.org/about-asan/about-autism/

Bakan, M. (2018). Music and autism, representation and re-presentation: An ethnomusicological perspective. In E. Fein, \& C. Rios (Eds.), Autism in translation: An intercultural conversation on autism spectrum conditions (pp. 109-53). Palgrave Macmillan.

Botha, M., Hanlon, J., \& Williams, G. L. (2021). Does language matter? Identity-first versus person-first language use in autism research: A response to Vivanti. Journal of Autism and Developmental Disorders. https://doi.org/10.1007/s10803-020-04858-w

Bullus, E., \& Sesterka, A. (2020, April 1). Moving beyond autism awareness to autism acceptance. Psychology Today. https://www.psychologytoday.com/us/blog/insightsabout-autism/202004/moving-beyond-autism-awareness-autism-acceptance

Bury, S. M., Jellett, R., Spoor, J. R., \& Hedley, D. (2020). "It defines who I am" or "It's something I have": What language do [autistic] Australian adults [on the autism spectrum] prefer? Journal of Autism and Developmental Disorders. https://doi.org/10.1007/s10803-020-04425-3.

Cage, E., Di Monaco, J., \& Newell, V. (2018). Experiences of autism acceptance and mental health in autistic adults. Journal of Autism and Developmental Disorders, 48(2), 473484. https://doi.org/10.1007/s10803-017-3342-7

Cassidy, S. A., Gould, K., Townsend, E., Pelton, M., Robertson, A. E., \& Rodgers, J. (2019). Is camouflaging autistic traits associated with suicidal thoughts and behaviours? Expanding the interpersonal psychological theory of suicide in an undergraduate student sample. Journal of Autism and Developmental Disorders, 1-11. https://doi.org/ 10.1007/s10803-019-04323-3

CAST. (2018). Universal design for learning guidelines version 2.2. http://udlguidelines.cast.org

Center for Universal Design. (1997). The principles of universal design. North Carolina State University. https://projects.ncsu.edu/ncsu/design/cud/pubs_p/docs/poster.pdf

Centers for Disease Control and Prevention. (CDC). (2021). Signs and symptoms of autism spectrum disorders. Autism Spectrum Disorder. https://www.cdc.gov/ncbddd/autism/signs.html

Dickter, C. L., Burk, J. A., Zeman, J. L., \& Taylor, S. C. (2020). Implicit and explicit attitudes toward autistic adults. Autism in Adulthood, 2(2)

https://doi.org/10.1089/aut.2019.0023

Eng, A. (2017, June 28). Neurodiversity in the library: One librarian's experience. In the Library with a Lead Pipe. http: / / www.inthelibrarywiththeleadpipe.org/2017/neurodiversityin-the-library/

George, K. (2020). DisService: Disabled library staff and service expectations. In V.A. Douglas, \& G. Joanna (Eds.), Deconstructing service in libraries: Intersections of identities and expectations (pp. 96-123). UNLV. https://digitalscholarship.unlv.edu/lib_articles/681

The International Journal of Information, Diversity, \& Inclusion, 5(3), 2021

ISSN 2574-3430, jps.library.utoronto.ca/index.php/ijidi/index

DOI: 10.33137/ijidi.v5i3.36196 
Goodman, L.A. (1961). Snowball sampling. Annals of Mathematical Statistics, 32(1), 148-170. https://doi.org/10.1214/aoms/1177705148

Harmuth, E., Silletta, E., Bailey, A., Adams, T., Beck, C., \& Barbic, S. P. (2018). Barriers and facilitators to employment for adults with autism: A scoping review. Annals of International Occupational Therapy, 1(1), 31-40. https://doi.org/10.3928/2476122220180212-01

Hatfield, M., Falkmer, M., Falkmer, T., \& Ciccarelli, M. (2017). “Leaps of faith”: Parents' and professionals' viewpoints on preparing adolescents on the autism spectrum for leaving school. Journal of Research in Special Educational Needs, 17(3), 187-197. https://doi.org/10.1111/1471-3802.12377

Hollich, S. (2020). What it means for a disabled librarian to "pass." The International Journal of Information, Diversity, \& Inclusion, 4(1), 94-107. https://doi.org/10.33137/ijidi.v4i1.32440

Hull, L., Mandy, W., Lai, M. C., Baron-Cohen, S., Allison, C., Smith, P., \& Petrides, K. V. (2019). Development and validation of the camouflaging autistic traits questionnaire (CAT-Q). Journal of Autism and Developmental Disorders, 49(3), 819-833. https://doi.org/10.1007/s10803-018-3792-6

Kapp, S. K., Gillespie-Lynch, K., Sherman, L. E., \& Hutman, T. (2013). Deficit, difference, or both? Autism and neurodiversity. Developmental Psychology, 49(1), 59-71. https://doi.org/10.1037/a0028353.

Kenny, L., Hattersley, C., Molins, B., Buckley, C., Povey, C., \& Pellicano, E. (2016). Which terms should be used to describe autism? Perspectives from the UK autism community. Autism, 20(4), 442-462. https://doi.org/10.1177/1362361315588200

Lawrence, E. (2013). Loud hands in the library: Neurodiversity in LIS theory \& practice. Progressive Librarian, (41), 98-109. http://www.progressivelibrariansguild.org/PL/PL41/098.pdf

Lindsay, S., Osten, V., Rezai, M., \& Bui, S. (2019). Disclosure and workplace accommodations for people with autism: A systematic review. Disability and Rehabilitation, 43(5), 597610. https://doi.org/10.1080/09638288.2019.1635658

Lu, W. (2020, July 23). How equity is lost when companies hire only workers with disabilities. The New York Times. https: / / www. nytimes.com/2020/07/23/business/disabilitydiscrimination-jobs-sheltered-workshop.html

Lund, B. D. (2018). Redefining opportunity for the library employee with autism: A model of positive behavioral support for library management. Journal of Library Administration, 58(5), 434-448. https://doi.org/10.1080/01930826.2018.1468192

McMahon, B. T., Roessler, R., Rumrill, P. D., Hurley, J. E., West, S. L., Chan, F., \& Carlson, L. (2008). Hiring discrimination against people with disabilities under the ADA: Characteristics of charging parties. Journal of Occupational Rehabilitation, 18(122). https://doi.org/10.1007/s10926-008-9133-4

The International Journal of Information, Diversity, \& Inclusion, 5(3), 2021 
Muir, R., Thompson, K. M., \& Qayyum, A. (2020). The diversity we seek: A document analysis of diversity and inclusion in the Australian library and information sector job advertisements. Journal of the Australian Library and Information Association, 69(4), 473-495. https://doi.org/10.1080/24750158.2020.1812023

Neely, B. H., \& Hunter, S. T. (2014). In a discussion on invisible disabilities, let us not lose sight of employees on the autism spectrum. Industrial and Organizational Psychology, 7(2), 274-277. https: //doi.org/10.1111/iops.12148

Oliver, M. (2013). The social model of disability: Thirty years on. Disability \& Society, 28(7), 1024-1026. https://doi.org/10.1080/09687599.2013.818773

Oud, J. (2019). Systemic workplace barriers for academic librarians with disabilities. College \& Research Libraries, 80(2), 169-194. https://doi.org/10.5860/crl.80.2.169

Randstad. (2021, April 7). Adapting your interview process to support people on the autism spectrum. Corporate Culture. https://www.randstad.ca/workplace-insights/corporateculture/how-to-interview-someone-autism-spectrum/

Schomberg, J., \& Highby, W. (2020). Beyond accommodation: Creating an inclusive workplace for disabled library workers. Library Juice Press.

Spectrum, J. (2017, April 16). Perspectives on an autistic children's librarian. ALSC Blog. http://www.alsc.ala.org/blog/2017/04/perspective-autistic-childrens-librarian/

Strauss, A., \& Corbin, J. (1998). Basics of qualitative research: Techniques and procedures for developing grounded theory. Sage Publications, Inc.

Strub, M. R., \& Stewart, L. (2010). Case study: Shelving and the autistic employee. Journal of Access Services, 7(4), 262-268. https://doi.org/10.1080/15367967.2010.508369

Taylor, J. L., Henninger, N. A., \& Mailick, M. R. (2015). Longitudinal patterns of employment and postsecondary education for adults with autism and average-range IQ. Autism, 19(7), 785-793. https://doi.org/10.1177/1362361315585643

Tesch, R. (1990). Qualitative research: Analysis types and software tools. Routledge.

Tumlin, Z. (2019). “This is a quiet library, except when it's not:” On the lack of neurodiversity awareness in librarianship. Music Reference Services Quarterly, 22(1-2), 3-17. https://doi.org/10.1080/10588167.2019.1575017

Vornholt, K., Uitdewilligen, S., \& Nijhuis, F. J. (2013). Factors affecting the acceptance of people with disabilities at work: A literature review. Journal of Occupational Rehabilitation, 23(4), 463-475. https://doi.org/10.1007/s10926-013-9426-0

Whetzel, M. (n.d.). Interviewing tips for applicants with autism spectrum disorders (ASD). Job Accommodation Network, 10(1). https://askjan.org/publications/consultantscorner/vol10iss01.cfm

Wyss, P. (2014). Asperger's in academia: A personal narrative of failure and success from a 
librarian with Asperger's syndrome. In T. Bastiaens (Ed.), E-Learn: World Conference on E-Learning in Corporate, Government, Healthcare, and Higher Education (pp. 21092114). https: //www.learntechlib.org/primary/p/148975/

Amelia Anderson (amanders@odu.edu) is an assistant professor at Old Dominion University. She earned her MLIS and PhD from Florida State University, where she was a research assistant on two IMLS grants (Project PALS and Project A+) that developed training for librarians to better serve patrons on the autism spectrum. Her research interests lie at the intersection of neurodiversity and librarianship. She is currently the co-PI and project director of an IMLS planning grant which explores accessibility in public library makerspaces. Her book, Library Programming for Autistic Children and Teens, published by ALA Editions, is scheduled for publication in Spring, 2021. 